\title{
ANALISIS SEMIOTIKA JOHN FISKE DALAM TAYANGAN LENTERA INDONESIA EPISODE MEMBINA POTENSI PARA PENERUS BANGSA DI KEPULAUAN SULA
}

\author{
Trivosa Pah ${ }^{1}$, Rini Darmastuti ${ }^{2}$ \\ Universitas Kristen Satya Wacana \\ trivosapah@gmail.com ${ }^{1}$, rini.darmastuti@uksw.edu ${ }^{2}$
}

\begin{abstract}
Lentera Indonesia is one of the documentary programs by television station NET TV. This program displayed the story from the people who struggled to bring positive thinking and impact to the community. This program has a lot of signs and meanings. This article will be explained about Lentera Indonesia's program edition "Building the potential of the nation's next generation in Sula Island, North Maluku Province" which aired on May 6th, 2018 and is located in the village of Lekokadai, Sula Island, Nort Maluku Province. This article conducted to find out the meaning of this episode. This article used a critical paradigm which is approached by John Fiske's semiotic method, consist of reality level, representation level, and ideology level. Seen from every story that has been built from section 1 to 3, this program has been shown: 1. The struggles of a young girl named Yosa who have been fighting for education in remote areas in Indonesia, with a personality that is simple, creative, has a characteristic of leadership, and easy to blend with the people surrounding himself. 2. People besides the main character who inspires, struggles, and willingness the others in limited facilities and electricity.3. Shown the potential of this place which has been named by city of music in Indonesia.
\end{abstract}

Keywods: John Fiske; semiotic; Lentera Indonesia; Sula Island.

\begin{abstract}
ABSTRAK
Lentera Indonesia, merupakan salah satu program bergenre documenter yang dimiliki oleh stasiun televisi swasta NET.TV. Program ini menampilkan kisah perjuangan anak bangsa yang membawa dampak positif bagi masyarakat, yang sarat akan tanda-tanda dan pemaknaan. Tulisan ini akan membahas tayangan Lentera Indonesia episode "Membina Potensi Para Penerus Bangsa di Kepulauan Sula, Maluku Utara" yang tayang pada 6 Mei 2018 dan berlokasi di desaLekokadai, Kepulauan Sula, Provinsi Maluku Utara. Tujuannya adalah untuk mengetahui makna dari episode ini. Tulisan ini didasarkan pada paradigma kritis dengan mendekatan semiotika John Fikse. Kodekode sosial yang dikemukan oleh John Fiske terbagi menjadi 3 tahapan yaitu level realitas, level representatif dan level ideologi. Dilihat dari setiap cerita yang dibangun dari segmen 1 sampai 3, tayangan ini ingin menunjukkan 1. Perjuangan seorang anak muda yang bernama Yosa dalam memperjuangkan pendidikan di daerah pelosok yang ada di Indonesia, dengan kepribadian yang sederhana, kreatif, tegas, memiliki sifat pemimpin, dan mudah berbaur dengan lingkungan sekitar. 2. Pelajaran hidup yang menginspirasi, semangat perjuangan, kebaikan hati dan kerelaan memberi yang datang dari tokoh-tokoh lain selain tokoh utama, dalam keterbatasan fasilitas serta listrik 3. Potensi anak daerah Maluku yang dijuluki sebagai city of music in Indonesia.
\end{abstract}

Kata Kunci: Semiotika, John Fiske, Lentera Indonesia, Kepulauan Sula 


\section{PENDAHULUAN}

Memasuki abad ke-20, pertelevisian Indonesia berkembang pesat dan melahirkan banyak stasiun televisi. Hingga saat ini, terdapat lebih dari 300 stasiun televisi, mulai dari stasiun televisi nasional, swasta maupun lokal. Tayangan-tayangan dalam stasiun ini pun beragam, seperti berita, hiburan, musik, talkshow, drama, olahraga, kerohanian, kuis, film dan lain-lain. Setiap tayangan televisi ini, mempunyai target sasaran yang berbeda-beda berdasar pada visi dan misi tayangan tersebut. Televisi merupakan salah satu media massa yang terdiri dari kombinasi radio (broadcast) dan film (moving picture). Akibatnya, penonton di rumah-rumah ketika menangkap siaran TV, maka tanpa disadari mereka juga akan menangkap siaran radio. Effendi (1993:174) mengatakan, dalam setiap unsur tanyangan televisi selalu ada unsur-unsur radio. Penonton tidak mungkin dapat melihat gambar-gambar yang bergerak pada layar televisi, jika tidak ada unsur-unsur film.

Disisi yang lain, televisi mempunyai pengaruh yang sangat kuat dalam membentuk perilaku khalayak. Hal ini seperti yang dikatakan oleh Prof. Dr. R. Mar'at dari Unpad, bahwa tayangan televisi pada umumnya mempengaruhi sikap, pandangan, persepsi, dan perasaan para penonton. Inilah kekuatan televisi dan seringkali dipahami oleh masyarakat kita sebagai sebuah kewajaran. Jadi, bila ada hal-hal yang mengakibatkan penonton terharu, terpesona, atau latah, bukanlah sesuatu yang istimewa, sebab salah satu pengaruh psikologis dari televisi adalah keperkasaannya yang seakan-akan menghipnotis penonton, sehingga mereka terhanyut dalam keterlibatan pada kisah atau peristiwa yang dihidangkan televisi (Effendi, 2002:122).

Berbicara tentang tayangan televisi, ada dua komponen penting yang menjadi perhatian yaitu segi auditif dan segi visual. Kedua hal ini tidak dapat dipisahkan, karena pada umumnya penonton akan lebih tertarik pada sebuah tayangan di televisi dengan mempertimbangkan suara dan visualnya. Penonton akan tertarik dengan penyiar televisi atau orang-orang yang tampak di layar kaca televisi, ketika 'tokoh-tokoh' yang tampil tersebut berparas menarik dan memiliki suara yang baik. Pada dasarnya, pengaruh dari televisi akan cepat diterima terutama pada aspek kognitif yang meliputi pengetahuan akan kejahatan, aspek afektif meliputi perasaan atau emosi akan tayangan kekerasan bahkan aspek behavioural yang meliputi tindakan untuk meniru adegan kekerasan (Wulandari, 2016:83). Dengan kata lain, keperkasaan televisi dalam mempengaruhi khalayak dan dalam membangun pengaruh pada aspek kognitif, afektif dan sampai aspek perilaku, sangat dipengaruhi oleh faktor audio dan visual dari tanyangan tersebut.

Berdasarkan dari pemahaman ini, maka setiap stasiun televisi berusaha untuk membuat tayangan yang menarik dengan mempertimbangan keseimbangan pada aspek auditif dan visual. Tujuannya adalah supaya pesan dari setiap tayangan mudah diterima oleh khalayak dan mampu membawa pengaruh pada tataran kognitif, afektif dan behavioral. Salah satu televisi yang sangat memperhatikan hal ini adalah NetTV. PT. Net Mediatama 
Televisi merupakan stasiun swasta yang resmi mengudara di pertelevisian Indonesia sejak tanggal 26 Mei 2013. Stasiun televisi ini memiliki kategori program tayangan, yaitu: Net News, Net Entertaiment, Net Talkshow, Net Classic, Net Sitcom, Net Documentaru, Net Magazie, Net series, Net Musikdan Net Special.

Salah satu tayangan dalam kategori Net Documentary adalah Lentera Indonesia. Tayangan yang ada sejak tahun 2013 ini mengangkat kisah nyata perjuangan kemanusiaan di pelosok Negeri yang membawa dampak positif bagi masyarakat. Burdarasi 30 menit di layar kaca, tayangan ini seolah-olah berusaha menayangkan permasalah yang dekat dengan keseharian masyarakat, seperti pendidikan, kesejahteraan, sosial dan ekonomi. Layaknya tayangan televisi pada umumnya, program Lentera Indonesia memiliki fungsi informatif, edukatif, hiburan, dan sarat dengan makna pesan yang hendak disampaikan kepada penonton. Pesan-pesan tersebut ditampilkan dalam mekanisme lambang atau tanda-tanda berupa penampilan, percakapan, suara, lingkungan dan sebagainya. Terkait dengan pesan-pesan yang ditampilkan dari setiap episode dari program Lentera Indonesia, maka yang menjadi pertanyaan adalah makna apa yang terkandung dari setiap pesan yang ingin disampaikan dari tayangan tersebut? Pesan-pesan apa yang ingin disampaikan melalui simbol-simbol yang digunakan dari setiap tayangan? Pembelajaran apa yang ingin disampaikan kepada masyarakat, melalui simbol-simbol yang digunakan dari setiap episode dari program Lentera Indonesia?

Untuk menjawab beberapa pertanyaan diatas, dapat dilakukan dengan mengungkapkan makna dari pesan yang disampaikan melalui cerita dari episode program Lentera Indonesia yang sarat akan simbol dan tanda. Pendekatan John Fiske dalam kajian semiotika, merupakan salah satu cara yang bisa kita gunakan. Dalam kajian semiotika ini, John Fiske menjelaskan tentang kode-kode sosial yang digunakan di acara televisi. Dia membagi kedalam 3 level yaitu level realitas, level representatif dan level ideology. John Fiske merupakan seorang ahli filsuf dan sejarawan asal Amerika Serikat yang lahir pada tahun 1939. Melalui buku yang berjudul Television Culture (1987), dia mengkritisi Łayangan televisi yang berkaitan dengan isu ekonomi dan budaya. John Fiske menerapkan semiotika pada teks-teks media dengan mengikuti tradisi post strukturalisme dan menolak gagasan tentang penonton yang menerima hasil produksi media massa tanpa berpikir kritis. John Fiske mengatakan bahwa peristiwa yang ditayangankan dalam dunia televisi telah dienkode oleh kode-kode sosial yang terbagi dalam 3 level, yaitu realitas, representasi dan ideologi. Menurut Fiske, kode-kode yang muncul atau digunakan dalam acara-acara televisi saling berhubungan sehingga nantinya akan membentuk sebuah makna, makna inilah yang merupak an proses berpikir dari penonton.

Dalam tulisan ini, penulis akan menggunakan tiga level (level realitas, level representatif dan level ideologi) yang disampaikan oleh John Fiske, untuk menemukan makna yang tersirat dari episode pada tayangan Lentera Indonesia. Dengan berpijak pada peringkat Indeks Pembangunan, maka penulis mengangkat Program Lentera Indonesia episode 
“Membina Potensi Para Penerus Bangsa di Kepulauan Sula, Maluku Utara” yang tayang pada tanggal 6 Mei 2018 dan berlokasi di desaLekokadai, Kepulauan Sula, Provinsi Maluku Utara sebagai bahan kajian pada tulisan ini.

Berdasarkan data Badan Pusat Statistik, Indek Pembangunan Manusia pada tahun 2018, Kepulauan Sula khususnya desa Lekokadai, pulau Morotai yang digunakan sebagai latar tempat pengambilan shooting episode pada program Lentera Indonesia menduduki peringat 9 dari 10 pulau yang ada di kepulauan Sula. Indeks Pembangunan Manusia (IPM) merupakan suatu ukuran prestasi suatu daerah atau wilayah atau Negara dalam dimensi pembangunan manusia. Dimensi pembangun manusia terbagi atas tiga yaitu dimensi kesehatan, dimensi pendidikan dan dimensi ekonomi (Badan Pusat Statistik Kabupaten Sula, 2018:9). Berdasarkan data tersebut, maka penulis tertarik untuk mengetahui bagaimana analisis semiotika John Fiske dalam pembentukan makna melalui 3 tahapan, yaitu: level realitas, level representatif dan level ideologi dalam tayangan Lentera Indonesia episode Membina Potensi Para Penerus Bangsa di Kepulauan Sula, Maluku Utara" yang tayang pada 6 Mei 2018.

\section{TINJAUAN PUSTAKA}

\section{Media Massa}

Soyomukti dalam buku Pengantar Ilmu Komunikasi (2010:198) mengatakan bahwa istilah media massa merujuk pada alat atau cara terorganisasi untuk berkomunikasi secara terbuka dan dalam jarak jauh kepada banyak orang (khalayak) dalam jarak waktu yang ringkas. Bukan hanya sekedar alat, media massa juga institusionalisasi dalam masyarakat sehingga terjadi proses pengaturan terhadap alat itu oleh masyarakat melalui kekuasan yang ada maupun melalui kesepakatan-kesepakatan lain.

Denis McQuail dalam buku Teori Komunikasi Massa (1987:200) menguraikan definisi dan fungsi media masa sebagai : a. Industri pencipta lapangan kerja, barang, dan jasa serta menghidupkan industri lain; b. Sumber kekuatan, alat control, manajemen dan inovasi masyarakat; c. Wahana pengembangan kebudayaan, tata cara, mode, gaya hidup, dan norma; dan d. Sumber dominan pencipta citra individu, kelompok dan masyarakat.

Menurut McQuail (1987), dalam kehidupan sehari-hari, kita bisa melihat karakteristik media massa antara lain publisitas, universalitas, periodisasi, kontinuitas dan aktualitas. Publisitas menjelaskan bahwa media massa adalah produk pesan dan informasi yang disebarluaskan kepada publik, khalayak, atau orang banyak, massa. Universalitas mengatakan bahwa pesannya bersifat umum dan tidak dibatasi pada tema-tema khusus, berisi segala aspek kehidupan, dan semua peristiwa di berbagai temapt, juga menyangkut kepentingan umum karena sasaran dan pendengarnya orang banyak (masyarakat umum). Periodisasi merupakan waktu terbit atau tayangannya bersifat tetap atau 
berkala, misalnya harian atau mingguan, atau siaran sekian jam per hari. Kontinuitas menunjukkan karakteristik media massa yang berkesinambungan atau terus menerus sesuai dengan periode mengudara atau jadwal terbit. Aktualitas menunjukkan bahwa media massa berisi hal-hal baru, seperti informasi atau laporan peristiwa terbaru, tips baru, dan sebagainya. Aktualitas juga berarti kecepatan penyampain informasi kepada publik.

Peran media dalam membentuk opini publik dan mengarahkan opini massa sesuai kepentingan yang berkaitan dengan beberapa pendekatan. Salah satu teori yang paling dikenal adalah "Agenda Setting Theory". Diyakini bahwa agenda media dapat mengatur agenda publik, dan agenda publik pada gilirannya dapat mengatur agenda pemerintah. Artinya, masalah apa pun yang diekspose terus menerus oleh banyak media pada waktu yang sama, dapat dengan cepat mempengaruhi topik pembicaraan di masyarakat luas (Soyomukti, 2017:199).

Media massa dibagi menjadi beberapa bentuk (Soyomukti, 2017 : 200-201), yakni pertama, Media Cetak, contohnya adalah surat kabar. Media cetak memiliki ciri sebagai berikut a. Pesan yang disampaikan memuat unsur reproduksi utama, yaitu symbol, verbal, gambar dan warna; b. Bersifat portable: relative nyaman dan mudah dibawa kemana-mana; bisa dibaca di mana saja dan membacanya dapat dilakukan berulangulang; c. Unsur umpan balik yang ada juga bersifat verbal (surat pembaca, kritik) dan non-verbal (penjualan); d. Isi pesan yang ada utamanya bersifat informatif; bagi penyampaian gagadan dari masyarakat (biasanya ada ruang gagasan dan opini, yang disampaikan oleh masyarakat dalam bentuk tulisan), selain juga memuat perdebatan atas isu yang menjadi polemic; e. Relatif berbas dari regulasi (kontril melalui peraturan), terutama di dalam masyarkat yang menganut system pers bebas; dan f. Wilayah jangkauannya masih didominasi oleh masyarkat perkotaan(urban). Kedua, Media Audio Visual, misalnya televisi. Media Audio mimiliki ciri-ciri : a. Pesan yang disampaikan melalui unsur reproduksi yang bersifat verbal, gambar, warna suara dan gerakan; b. Tidak portable, karena tidak bisa dibawa kemana-mana, kalua mau bisa saja, tetapi televisi adalah peralatan teknologi komunikasi yang berat; c. Pesantidak juga bisa diulangkarena tampilan pesan sekilas sehingga cepat berlalu (tidak bisa ditinjau ulang); d. Bersifat serempak ; e. Umpan balik: verbal dan non-verbal; e. Industri komunikasi audio visual ditunjang oleh iklan, iuran dan subsidi pemerintah; f. Karakter publik dan pengaturan yang ketat (regulated media); dan g. Berisi aneka ragam bentuk informasi dan pesan (berita, hiburan, pendidikan, dan lain-lain)

\section{Televisi}

Sejarah pertelevisian Indonesia mulai akhir tahun 1962 dengan lahirnya TVRI milik pemerintah. Tahun 1989 dengan mengacu pada SK Menteri Penerangan No. 190/Kep/1987 Oktober 1987 tentang ijin pembukaan saluran stasiun televisi swasta, muncul RCTI (1989), SCTV (1990), TPI (1991), AN-Teve (1993), Indosiar (1995), Metro TV (2000), TV 7 (2001), Trans TV (2002), Global TV (2002), TV One (2008). Hadirnya 
televisi swasta ini disambut oleh pers Indonesia sebagai alternatif yang akan memperbaiki kualitas dan tayangan TVRI (Kitley, 2001: 268).

Layar televisi Indonesia dipenuhi oleh ratusan program jurnalistik yang isinya relatif berseberangan antara isu-isu aktual yang terkait kepentingan publik seperti bencana banjir, gempa, tsunami, dan kelaparan dengan isu-isu privat seperti skandal seks, korupsi dan perilaku menyimpang lainnya di kalangan selebritis politik dan hiburan (Masduki, 2008: 158).

Memasuki tahun 2000-an, pertelevisian di Indonesia mulai berkembang pesat dan melahirkan banyak siaran televisi di Indonesia, baik yang jaringan nasional maupun lokal. Genre dalam setiap tayangan televisipun beragam, masing-masing bersaing menghadirkan tayangan yang berbeda dan kreatif sehingga disukai oleh masyarakat Indonesia.

Dalam membuat sebuah program televisi, semua orang yang terlibat dalam pembuatan program, mulai dari produser, jurnalis, sutradara, editor, dan quality control harus mengikuti prosedur yang ada di stasiun televisi tersebut untuk menghasilkan program yang berkualitas. Pembuatan program televisi biasanya melewati berbagai tahap dan melibatkan banyak orang. Fachruddin (2016:2-10) dengan mengacu pada pendapat Herbert Zettl (seorang professor penyiaran dan seni berkomunikasi pada media elektronik di San Fransisco University), menuliskan tahapan sebuah produksi televisi adalah sebagai berikut: (1) Prepoduction planning : from idea to script (a) Program Idea, produser biasanya akan mencari dan mengembangkan ide program sesuai dengan konsep acara yang diinginkan target audience (b) Production Models, suatu metode untuk melihat langsung keterkaitan antara ide yang sudah ada dan apa yang diharapkan bisa terjadi pada audience yang dituju. (c) Program Proposal, yang terdiri atas: program title, program objective, target audience, show format, Show treatment, production method, dan tentative budget. (2) Preproduction Planning : Coordination (a) Schedules, produser membuat jadwal serealistis dan berpegang teguh pada jadwal tersebut, menetapkan orang-orang yang terlibat, melakukan apa, kapan dan dimana. (b) Permits and Clearances, membuat surat permohonan ijin akan sangat membantu dalam kelancaran produksi. (c) Promotion, melakukan promosi merupak an langkah vital sehingga program yang berkualitas diketahui banyak orang.Secara umum, promo TV terdiri dari 2 bagian, yaitu: Promo on air. Segala sesuatu yang dijadikan promosi oleh stasiun televisi khususnya dengan menggunakan fasilitas media televisinya, seperti: trailer, teaser, super impose, running text, tag on, promo continuity, dan Promo off air. Promo yang tidak menggunakan televisi sebagai media promosinya, seperti: media cetak, Internet, Billboard, Transit, media penyiaran, dan Pamflet/brosur. (3) Line Producer: Host and Wacthdog. Selanjutnya, tugas akan dilanjutkan oleh seorang Line Producer yang akan menjadi penanggung jawab harian produksi dan mengawasi jalannya produksi. (4) Postproduction Activities. Jika programnya di produksi secara live, maka dibutuhkan kehati-hatian yang tinggi, dan jika produksi live on tape (rekaman), maka harus 
berkoordinasi dengan postproduction editing, diantaranya: (a) Postproduction editing, semua hasil liputan akan digabung menjadi satu, kemudian menyusunnya berdasar perencanaan naskah yang sudah dibuat sebelumnya. Hal-hal yang dilakukan dalam fase ini adalah mixing audio, subtitling,color correction dan sebagainya, dan sebelum final editing, maka perlu di preview oleh produser untuk melakukan koreksian terakhir pada program yang akan disiarkan tersebut. (b) Evaluation and feedback, tidak menitik beratkan pada tuduhan dan saling menyalahkan melainkan lebih meminta masukan agar bisa diperbaiki di produksi selanjutnya. (c) Record keeping, pastikan setelah selesai produksi, semua hasil master edit disimpan dengan baik, aman dan terlindungi dari kerusakan air, kelembapan udara dan lain sebagainya.

\section{Semiotika John Fiske}

Semiotika adalah cabang keilmuan tentang tanda yang mempunyai prinsip, sistem dan aturan-aturan yang khusus dan baku. Semiotika berbeda dengan ilmu pengetahuan alam yang memiliki sifat kepastian, objektivitas dan ketunggalan, karena semiotika dibangun lebih terbuka bagi berbagai interpretasi. Sebagai cabang ilmu yang mempunyai lingkup kajian luas dan meliputi hampir semua bidang kehidupan, mengakibatkan terciptanya cabang-cabang semiotika khusus, yaitu: semiotika seni, semiotika kedokteran, semiotika binatang, semiotika arsitektur, semiotika fashion, semiotika film, semiotika sastra dan semiotika televisi.

Semiotika membantu untuk menafsirkan berbagai tanda komunikasi, baik tanda alam maupun tanda buatan, semiotika mampu untuk menafsirkan makna-makna baik yang tersirat maupun tersurat, karena pada dasarnya semiotika berdasarkan pada logika atau subjektivitas si penafsir itu sendiri, hal inilah yang memunculkan beberapa aliran semiotika, seperti aliran semiotika strukturalisme, pragmatism, post-modernisme dan pembedanya adalah subjektivitas yang berdasar pada epistimologis, ontologis, aksiologis dan metodologis. Tanda-tanda yang ada dalam semiotika biasanya terdiri atas tanda natural, yaitu tanda yang terjadi secara alami, dan tanda konvensional, yaitu tanda yang khusus dibuat untuk komunikasi. Semiotika John Fiske mengikuti aliran poststrukturalisme, aliran ini lahir karena ketidaksetujuan terhadap aliran strukturalisme yang dipelopori oleh Ferdinand De Saussure yang mengatakan tanda dalam semiotika adalah sesuatu yang mengikat, dan tidak memberi kemungkinan akan terciptanya kreativitas tanda-tanda yang baru dan aliran post-strukturalisme menolak segala bentuk keterikatan dengan konvensi, aturan atau kode-kode baru, sebaliknya, ia membuka ruang bagi model-model bahasa dan pertandaaan yang kreatif, produktif, subversive, transformative, bahkan terkadang anarkis (Piliang, 2010:259). John Fiske (2010) dalam buku Culture and Communication studies: sebuah pengantar paling kompehenresif mengatakan komunikasi adalah berbicara satu sama lain. Pada tataran ini, komunikasi bisa dipahami dalam konteks dari pesan yang disampaikan melalui televisi, sebagai penyebaran informasi; atau bisa juga dalam bentuk komunikasi non verbal seperti gaya rambut ataupun kritik sastra John Fiske berasumsi bahwa semua komunikasi melibatkan tanda (sign) dan kode (codes). Tanda adalah artefak atau tindakan yang merujuk pada 
sesuatu yang lain di luar tanda itu sendiri. Tanda menandakan construct, dan kode adalah sistem dimana tanda-tanda diorganisasikan dan yang menentukan bagaimana tandatanda itu mungkin berhubungan satu sama lain. Asumsi lainnya adalah bahwa tandatanda dan kode-kode itu ditrasmisikan atau dibuat tersedia pada yang lain dan penerimaan tanda/kode/komunikasi adalah praktik hubungan sosial.

Dalam pandangan Fiske, sebuah peristiwa dalam tayangan televisi akan menjadi peristiwa televisi apabila telah dienkode oleh kode-kode sosial, yang dikonstruksi dalam tiga tahapan, yaitu realitas, representasi dan ideologi. Dalam tahapan realitas, acara televisi menampilkan realitas peristiwa dalam tampilan pak aian, lingkungan, perilaku, percakapan, gestur, ekspresi, suara dan sebagainya. Dalam artian bahwa, semua bentuk tayangan televisi benar-benar menampilkan sesuatu yang nyata atau sesuai fakta yang ada ditengah-tengah masyarkat. Sebagai contoh, apabila sedang memberitakan peristiwa tsunami, maka tayangan berita harus menampilkan gambar detik-detik tsunami, dampak tsunami, rumah-rumah yang terkena tsunami, dan sebagainya. Tahapan Representasi adalah tindakan menghadirkan atau mempresentasikan sesuatu lewat sesuatu yang lain di luar dirinya, biasanya berupa tanda atau simbol (Piliang, 2010:19). Representasi dalam tayangan televisi berkaitan dengan technical codes, seperti kamera, lighting, editing, $\mathrm{m}$ usik dan suara, elemen-elemen inilah yang kemudian ditransmisikan ke dalam kode representasional yang dapat mengaktualisasikan realitas dalam tayangan televisi. Sedangkan tahapan Ideologi adalah sistem kepercayaan dan sistem nilai yang direpresentasi dalam berbagai media dan tindakan sosial (Piliang, 2010:16). Dalam tahap ini, semua elemen diorganisasikan dan dikategorikan dalam kode-kode ideologis, seperti patriakhi, individualisme, ras, kelas, materialisme, kapitalisme dan sebagainya.

\section{METODE PENELITIAN}

Tulisan ini didasarkan pada hasil penulisan yang dilakukan dengan menggunakan pendekatan analisis semiotik John Fiske dengan menggunakan paradigma kritis. Wimmer \& Dominick dalam Kriyantono (2012:48), menyebut paradigma adalah seperangkat teori, prosedur dan asumsi yang diyakini oleh seseorang tentang bagaimana melihat atau memandang dunia, dalam penulisan ini paradigma yang digunakan adalah kritis. Penulisan ini menghendaki pengamatan secara menyeluruh dari semua isi program Lentera Indonesia episode "Membina Potensi Para Penerus Bangsa di Kepulauan Sula, Maluku Utara” yang tayang pada 6 Mei 2018 pukul 14.30 WIB di NET.TV. Penulisan ini tidak menguji hipotesis atau membuat prediksi.

Dalam penulisan yang dilakukan, penulis mengacu pada 3 tahahapan dalam konsep semiotika Johnn Fiske, meliputi pertama, Realitias yang diamati dari penampilan, pak aian, tata rias, lingkungan, perilaku, dialog, gerakan, ekspresi, dan suara. Kedua, Representatif. Representatif diamati dari techinical codes seperti kamera, tata cahaya 
(lighting), penyuntingan (editing), musik dan suara (backsound). Ketiga, Ideologi yang meliputi patriakhi, individualisme, ras, kelas, materialisme dan kapitaslisme.

Data yang digunakan sebagai dasar dari tulisan ini adalah data primer dan data sekunder. Data primer diperoleh dari hasil pengamatan atau observasi terhadap objek penulisan dalam hal ini semua isi tayangan program Lentera Indonesia Episode "Membina Potensi Para Penerus Bangsa di Kepulauan Sula, Maluku Utara" yang tayang pada 6 Mei 2018 pukul 14.30 WIB di NET.Tv. Penulis akan mengamati secara menyeluruh agar mendapatkan penjelasan makna sesuai dengan kajian semiotika John Fiske. Data sekunder diperoleh dari hasil wawancara dengan produser, editor serta reporter dan video jurnalis program Lentera Indonesia yang meliput tayangan Lentera Indonesia Episode "Membina Potensi Para Penerus Bangsa di Kepulauan Sula, Maluku Utara", bukubuku teori semiotika komunikasi, film, dan media, da beberapa sumber yang diperoleh dari internet dan jurnal penulisan.

Analisis data yang digunakan dalam penulisan ini adalah analisi yang dikemukakan oleh John Fiske. Langkah-langkah dalam analisis data dalam penulisan ini dibagi kedalam tiga tahapan yaitu tahapan realitas, tahapan representasi dan tahapan ideologi, dimana ketiga tahapan ini, akan dideskripsikan berdasarkan interpretasi dari penulis terhadap makna yang sesungguhnya dibalik tanda-tanda yang ada tayangan Lentera Indonesia episode "Membina Potensi Para Penerus Bangsa di Kepulauan Sula, Maluku Utara” yang tayang pada 6, Mei 2018 pukul 14.30 WIB.

\section{HASIL DAN PEMBAHASAN}

Program Lentera Indonesia adalah program acara televisi di NET.TV yang termasuk dalam kategori Net. Documentary. Program acara televisi ini didasarkan pada struktur produksi televisi. Storey (2010: 12) mengatakan bahwa struktur produksi televisi mengangkat topik, reportase, agenda, peristiwa-peristiwa, persons, citra khalayak, definisi situasi dari sumber-sumber yang lain serta formasi-formasi diskursif lainnya dalam struktur politik dan sosial kultural yang lebih luas dimana struktur produksi televisi merupak an bagian yang dibedakan.

Tayangan Lentera Indonesia episode "Membina potensi para penerus bangsa di Kepulauan Sula, Maluku Utara" yang tayang pada Minggu, 6 Mei 2018 pukul 14.30 WIB menceritakan tentang Yosa Lano Vastia, seorang pengajar muda dari gerakan Indonesia Mengajar, sebuah gerakan penempatan sarjana menjadi guru bantu di pelosok Indonesia selama satu tahun. Pemudi berdarah Aceh ini, di tempatkan di kepulauan Sula, DesaLekokadai, Kecamatan Mangoli Barat, Maluku Utara. Yosa sudah menjalani pengabdian sebagai guru bantu selama 4 bulan di SD Inpres Lekokadai. 
Desa Lekokadai merupakan sebuah desa yang jauh dari ibukota Kabupaten. Untuk sampai ke desa Lekokadai, diperlukan waktu yang cukup lama dan jarak yang cukup jauh dari ibukota kabupaten, yaitu dengan menempuh perjalanan laut selama 6 jam dan dilanjutkan dengan perjalanan darat selama 1 jam. Desa Lekokadai merupakan salah satu desa di kepulauan sula dengan jumlah penduduk yang cukup banyak, yaitu 300 jiwa penduduk. Sayangnya, dengan jumlah penduduk sebesar itu, sektor pendidikan di desaLekokadai berada pada kondisi yang sangat menyedihkan. Desa ini hanya memiliki satu Sekolah Dasar, satu TK dan Paud.

Pada tayangan ini juga diceritakan tentang salah satu murid Yosa yang duduk dibangku kelas 6 SD Inpres Lekokadai. Murid tersebut memiliki nama lengkap Yulius Nggilo dan merupakan suku asli desa Lekokadai yaitu suku Kadai. Setiap harinya Yulius ditemani adiknya harus menempuh jarak 7 kilometer atau 45 menit perjalanan kaki menuju ke sekolah dan sepulang sekolah harus membantu orangtua di kebun demi memenuhi kebutuhan sehari-hari. Malam harinya Yulius harus belajar dengan ditemani lampu pelita karena aliran listrik belum sampai ke desanya.

Pada episode ini juga diceritakan tentang bangunan TK dan Paud yang masih menumpang di salah satu rumah warga yaitu rumah Murudin. Dalam proses pendidikan yang terjadi di desaini, bukan hanya Pak Murudin yang terlibat dengan memberikan fasilitas listrik dan meminjamkan ruangan untuk TK dan Paud, anak-anak pak Murudin juga turut ambil bagian sebagai pengajar, dan juga menceritakan tentang keseharian Yosa diluar kewajibannya sebagai guru bantu, Yosa juga sebagai anak angkat dari kepala Desa Lekokadai, pada hari libur sekolah, Yosa ikut membantu Ibunya Wa Jumiati untuk memetik sayur di kebun dan memberi makan ternak. Pada akhir episode ini menggambarkan kontribusi Yosa bagi SD Inpres Lekokadai ini, misalnya, ketika Yosa memberikan pelatihan untuk guru-guru yang ada di Sekolah Dasar itu untuk mengetik menggunakan laptop. Hal lain yang dilakukan Yosa adalah mengadakan senam setiap hari jumat dan melatih siswa kelas 6 untuk tampil menyanyi lagu "You Raise Me Up" untuk acara perpisahan kenaikan kelas ke jenjang SMP bersama-sama dengan orangtua para murid.

Secara lebih rinci, Tayangan Lentera Indonesia episode "Membina potensi para penerus bangsa di Kepulauan Sula, Maluku Utara" dirangkum dalam tabel 1 untuk menjelaskan segmen pertama, tabel 2 untuk menjelaskan segmen kedua dan tabel 3 untuk menjelaskan segmen ketiga dengan menggunakan pendekatan John Fiske yaitu dengan melihat dari sisi realitas, representasi dan ideologi. 
Tabel 1. Penjelasan Segmen 1

\begin{tabular}{|c|c|c|}
\hline Level Realitas & Level Representatif & Ideologi \\
\hline 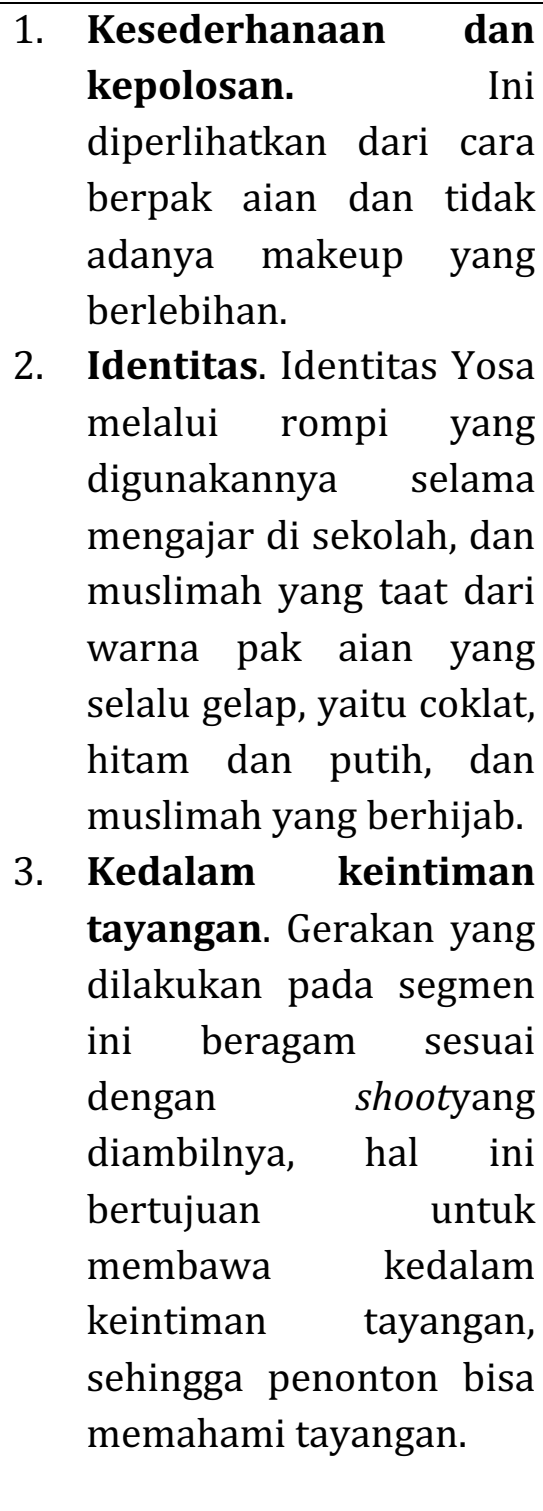 & $\begin{array}{l}\text { 1. Teknik Kamera. Teknik } \\
\text { kamera yang digunakan } \\
\text { dalam segmen } 1 \text { ini } \\
\text { adalah medium shootdan } \\
\text { long shoot, teknik medium } \\
\text { shoot biasanya digunakan } \\
\text { pada terjadi percakapan } \\
\text { atau wawancara dengan } \\
\text { objek, hal ini bertujuan } \\
\text { untuk memperlihatkan } \\
\text { mimik wajah dan ekspresi } \\
\text { tokoh secara jelas dan } \\
\text { membangun hubungan } \\
\text { intim dengan tokoh yang } \\
\text { sedang menjadi topik } \\
\text { bahasan pada segmen ini. } \\
\text { 2. Sudut pengambil. Sudut } \\
\text { pengambilan beragam. } \\
\text { Tujuannya adalah untuk } \\
\text { memberi kejelasan akan } \\
\text { aktifitas yang dilakukan } \\
\text { oleh yosa dan anak } \\
\text { muridnya, biasanya ini } \\
\text { dilakukan sebagai tanda } \\
\text { untuk mengganti gambar } \\
\text { selanjutnya yang akan } \\
\text { tampil. }\end{array}$ & 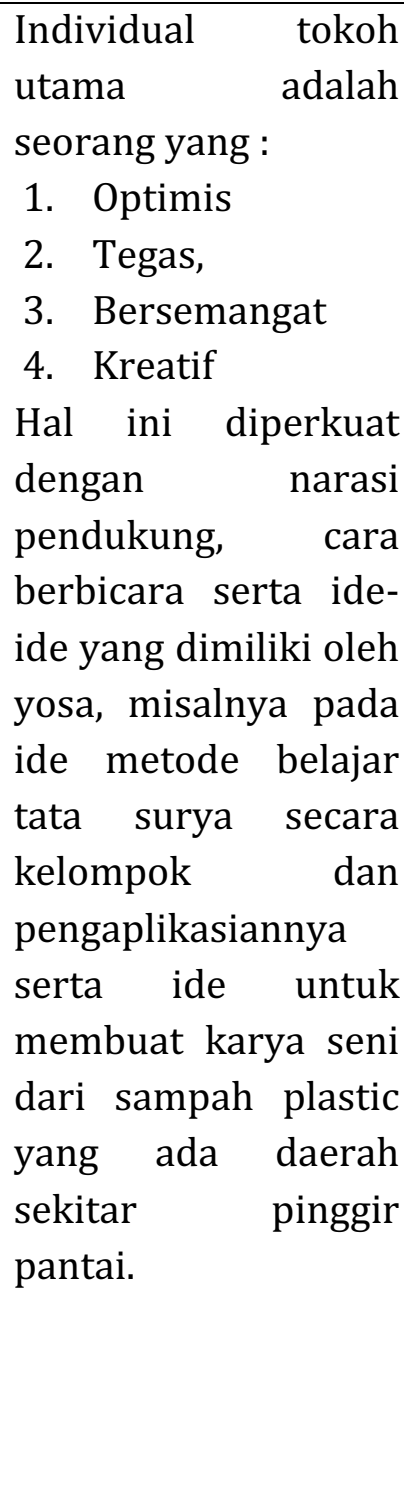 \\
\hline
\end{tabular}

Secara keseluruhan Segmen 1 ini terdiri atas shoot prolog atau pembuka, shoot pantun, shoot belajar tata surya dan shoot mengolah sampah. Maka dapat dilihat bahwa segmen 1 ini ingin membawa penonton untuk melihat sisi pendidikan dari desa Lekokadai, dan juga untuk memperkenalkan Tokoh Utama, yaitu Yosa Lano Vastia terkait kesehariannya sebagai Guru di SD Inpres Lekokadai.

Pemaknaan tayangan berdasar analisis John Fiske terbagi kedalam 3 Level yaitu level realitas, level representatif dan level ideologi. Level Realitas dalam tayangan ini menunjukkan banyak makna yang diperlihatkan dari kode-kode sosial yang termasuk dalam kategori level ini, seperti: penampilan, riasan, makeup, perilaku, gerakan, ekspresi, cara berbicara dan lingkungan yang ada di dalam prolog hingga shoot tentang mengolah sampah plastik, Tokoh Utama pada segmen ini mendominasi tayangan dan diberi ruang 
untuk pengenalan dirinya baik melalui monolog maupun narasi, hal ini untuk membangun pengenalan dan hubungan intim tokoh utama.

Pada prolog, level realitas yang dibangun melalui penampilan, memberikan makna kepada Tokoh Utama, yaitu Yosa sebagai seorang muslimah sederhana dan polos, hal ini diperlihatkan dari penampilan, riasan dan makeup yang digunakan oleh Yosa, nampak tidak ada riasan dan makeup yang berlebihan. Pemilihan warna pakaian yang digunakan oleh Yosa dalam segmen 1 ini adalah bernuansa gelap, warna gelap dalam agama Islam, warna hitam melambangkan cinta dan bagi seorang muslimah adalah tidak memperlihatkan bentuk lekuk tubuh. Penampilan anak-anak pada prolog ini menunjukan kesederhanaan dan keceriaan, hal ini diperlihatkan dari cara berpakaian, dan warna baju yang digunakan oleh anak-anak yaitu kuning dan merah, serta tidak adanya riasan/makeup pada tampilan anak-anak tersebut. Level representatif, pada prolog yang dibangun melalui teknik kamera, settting/latar tempat, pencahayaan dan suara atau musik. Pada teknik kamera, digunakan 2 jenis pengambilan gambar, yaitu medium shootdan long shoot, hal ini bertujuan untuk menghasilkan komposisi gambar yang saling berhubungan untuk membangun mood dan membangun keintiman dengan para penonton diawal tayangan.

Level ideologi yang tercipta digambarkan pada ketegori Individualisme dari tokoh utama, bersumber dari narasi monolog Yosa, yang menunjukan Yosa adalah seseorang yang memiliki keyakinan dan optimis untuk menggali potensi tersembunyi anak-anak muridnya sehingga nantinya akan menjadi hal yang luar biasa, dan juga kategori ras. Yosa mengibaratkan anak-anak di Desa Lekokadai sebagai mutiara hitam, namun penggunaan kata ini tidak tepat untuk anak-anak di Desa Lekokadai, Maluku Utara, menurut Widarmi Wijana dalam buku Mutiara Hitam Potensi Papua yang Tersembunyi (2007:ix), Mutiara hitam adalah Julukan kepada anak-anak di Provinsi Papua yang bertubuh gelap dan kuat.

Pada shoot Pantun, Level realitas yang dibangun melalui penampilan, riasan dan makeup yang digunakan Yosa dan anak muridnya menggambarkan kesederhanaan dan kepolosan serta menggambarkan identitas Yosa sebagai pengajar dari Indonesia mengajar. Hal ini nampak dari rompi Indonesia Mengajar yang dia gunakan, yang menunjukkan lembaga yang menanggungnya ketika melakukan tugasnya sebagai guru di SD Inpres Lekokadai. Hal lainnya adalah cara berbicara anak murid yang membuat pantun dari bahasa seharihari masyarakat Maluku. Hal ini menunjukan kreatifitas kata per kata dalam pantun yang tidak terbatas. Pada level representatif, diperlihatkan teknik medium shoot dan long shoot. Kedua teknik ini bertujuan untuk mengiring penonton kepada aktiftas yang dilakukan oleh objek dalam gambar. Pada pencahayaan menggunakan pencahayaan natural dari matahari, hal ini menunjukan gambar yang natural dan sesuai dengan keadaan aslinya. Pemilihan musik pada shoot ini adalah music drum dengan tempo yang cepat, menunjukan semangat dan membangun mood energik dari anak-anak yang sedang belajar. Hal ini diperkuat dengan pendapat Himawan Pratista dalama bukunya memahami Film yang menjelaskan bahwa instrument musik degan tempo cepat biasanya 
digunakan untuk membangun mood yang energik. Pada level ideologi dibangun melalui kategori Individual melalui pengenalan tokoh utama dari narasi serta foto-foto pendukung. Hal ini bertujuan untuk membangun hubungan intim antara penonton dengan tokoh utama.

Pada shoot belajar tata surya, level realitas yang dibangun melalui gerakan dan ekspresi Yosa dan anak murid menunjukan keseriusan dalam belajar. Hal ini ditunjukkan dari fokus anak-anak ketika mendengar penjelasan yang diberikan oleh Yosa. Pada level representatif, teknik pengambilan kamera beragam, diantaranya medium shoot dan long shoot. Dengan sudut pengambilan gambar yang beragama yaitu low angle, high angel, dan over shoulder, semuanya ini digunakan untuk menghasilkan mood yang baik kepada penonton, sehingga penonton dapat memahami aktifitas yang dilakukan dengan jelas. Pada level ideologi, ditunjukkan dengan seorang Yosa yang memiliki kreatifitas dan ketegasan dalam memberi ilmu kepada anak muridnya. Hal ini diperlihatkan dari metode belajar yang digunakan Yosa serta cara berbicara yang lugas dan tegas terkait dengan metode yang ia gunakan.

Pada shoot mengolah sampah, level realitas diperlihatkan dari kondisi lingkungan di pesisir pantai yang penuh dengan sampah, baik sampah plastik maupun sampah dari tumbuhan laut yang terbawa ombak ke area pinggir pantai. Ada sebanyak satu karung sampah berukuran $20 \mathrm{~kg}$ berhasil dikumpulkan oelh Yosa dan anak-anak. Hal ini menunjukkan kondisi lingkungan Desa Lekokadai yang kotor. Pada level representatif, tetap menggunakan teknik pengambilan gambar secara medium dan long shoot, menunjukan objek diambil dengan berbagai sudut yaitu over shoulder, eye angle atau pengambilan gambar sejajar dengan mata. Pengambilan gambar ini menunjukkan bahwa objek memiliki ukuran sama seperti aslinya. Pada level ideologi, menggambar seseorang Yosa yang kreatif, hal ini diperlihatkan dari ide untuk mengajak anak muridnya untuk mengolah sampah plastik yang bertebaran di pinggir pantai. Kemudian Yosa mengajak murid-muridnya untuk membuat karya seni yang berasal dari sampah tersebut dan nantinya akan di pajang di dalam kelas.

Secara keseluruhan, segmen 1 ini menggambarkan keseharian yosa di sebagai guru bantu di sekolah SD Inpres Lekokadai. Yosa tak hanya mengajar di dalam ruang kelas, namun juga memanfaatkan lingkungan di luar sekolah untuk belajar, seperti halaman sekolah, dan pesisir pantai desa Lekokadai.

Tabel 2. Penjelasan Segmen 2

\begin{tabular}{|l|c|c|}
\hline Level Realitas & Level Representatif & \multicolumn{2}{|c|}{ Level Ideologi } \\
\hline 1. Sederhana dan polos. & 1. Teknik & 1. Individual. Individual \\
Ditunjukkan dengan & pengambilan. & dalam segmen ini \\
penampilan, riasan & Teknik pengambilan & beragama dengan \\
dan makeup yang & gambar sama seperti & ideologinya masing- \\
digunakan oleh para & pada segmen 1, yaitu & masing, tokoh utama \\
\hline
\end{tabular}




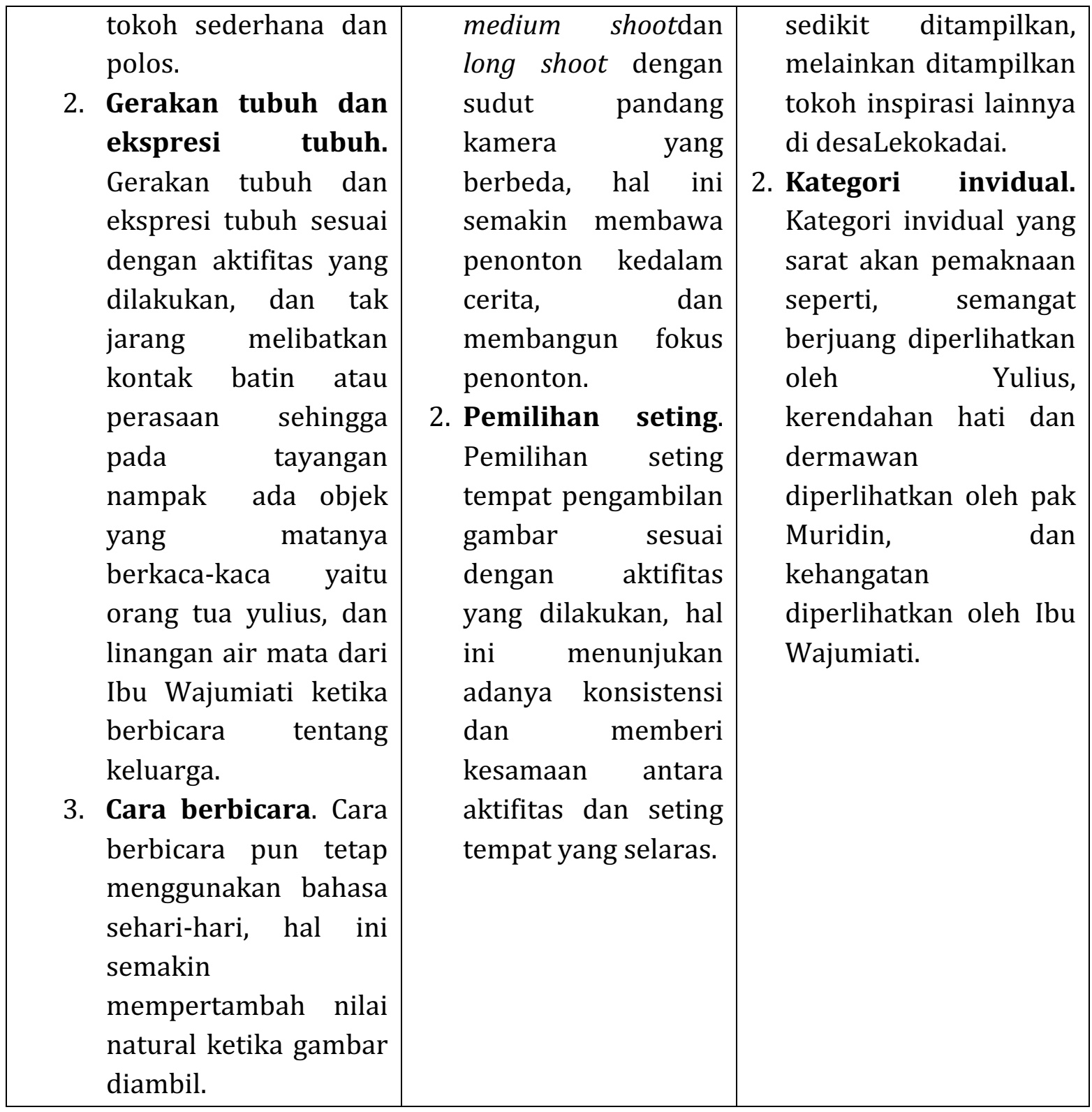

Pada segmen 2, tayangan terdiri dari shoot Yulius salah seorang murid Yosa yang berjuang untuk sekolah walau jarak antar sekolah dan rumah yang jauh. Tokoh yang lain adalah Pak Muridin yang memberi sebagian dari rumahnya untuk dijadikan sekolah. Segmen ini juga mengangkat tentang potret hidup Yosa ketika berada dirumah sebagai anak angkat dari Ibu kepala Desa Lekokadai yaitu Ibu Wajumiati. Berdasarkan tampilan gambar pada segmen 2 ini, maka pesan yang ingin disampaikan tidak hanya berasal dari tokoh utama, namun tokoh lain yang memiliki cerita kehidupan yang penuh inspirasi.

Pemaknaan tayangan berdasar analisis John Fiske terbagi kedalam 3 Level yaitu Level realitas, Level representatif dan Level ideologi. Level realitas dalam tayangan ini menunjukan banyak makna yang diperlihatkan dari kode-kode sosial yang termasuk dalam kategori, seperti penampilan, riasan, makeup, perilaku, gerakan, ekspresi, cara berbicara dan lingkungan. Pada level representatif diperlihatkan dalam kategori, seperti tenik kamera, pencahayaan, setting atau latar tempat, dan suara musik yang mengiringi. 
Level ideologi diperlihatkan dalam kategori individual dan ras. Semua komponen tayangan dalam segmen ini saling terkait dan membentuk serta menghasilan pemaknaan yang hendak disampaikan kepada penonton. Tokoh utama tidak terlalu ditampilkan pada segmen ini, melainkan tokoh lain yang memiliki nilai untuk menginspirasi melalui cerita dan perjalanan hidupnya.

Pada segmen ini ada shoot yang sama sekali tidak memiliki keterkaitan dengan tokoh utama, Yosa. Shoot tersebut adalah tentang Pak Muridin dengan cerita tentang sebagian rumah dan listrik yang direlakan untuk dipakai sebagai sekolah TK dan Paud di Desa Lekokadai. Penulis beranggapan bahwa tayangan ini hendak menyampaikan kepada penonton bahwa pemerintah daerah Desa Lekokadai masih memiliki kepedulian yang rendah dengan pendidikan sejak dini. Akibatnya, sekolah untuk TK dan Paud harus menumpang di rumah warga yang rela meminjamkan rumahnya dan memberikan listriknya untuk dijadikan sebagai tempat belajar.

Pada shoot Yulius, level realitas dibangun dalam penampilan, riasan, makeup, cara berbicara, lingkungan, gerakan dan ekspresi, semua kategori ini menggambarkan seorang anak yang hidupnya sederhana namun memiliki semangat untuk sekolah. Sekalipun harus menempuh jarak jauh untuk sampai ke sekolah, tetapi dia tetap semangat. Yulius harus menempuh perjalanan selama 45 menit dengan berjalan kaki ke Sekolahnya. Setelah pulang sekolah, Yulius harus membantu orang tuanya berkebun untuk memenuhi kebutuhan sehari-hari. Yulius tidak bisa bermain seperti anak seumuran dia pada umumnya. Pada malam hari Yulius tetap bersemangat untuk belajar, sekalipun hanya diterangi dengan sebuah lampu pelita, karena aliran listrik yang belum ada di desanya. Pada episode ini ditunjukkan ekspresi orang tuanya yang berkaca-kaca ketika meihat Yulius sedang belajar. Pada bagian ini memiliki makna pengharapan orang tua Yulius terhadap anaknya. Hal ini menunjukan adanya kontak batin atau perasaan yang mendalam untuk anaknya. Mengacu dari pendapat Joe Narvarro dalam Buku Cara Cepat Membaca Bahasa Tubuh tahun 2017, mengatakan bahwa ketika pandangan mata memandang ke arah lain ketika sedang berbicara, maka pada saat itu sedang terjadi proses berpikir dengan jelas tanpa harus terganggu dengan memandangi oranglain. Pandangan mata ke arah bawah menggambarkan seseorang sedang memproses perasaan, merenung atau bahkan bersikap sopan.

Pada level representatif diperlihatkan dari teknik kamera yang masih sama seperti pada segmen 1 yaitu medium shoot dan long shoot. Hal ini memiliki tujuan untuk menghasilkan mood dan keintiman antara tampilan gambar dengan penonton sehingga penonton bisa masuk dan memahami isi tayangan tersebut. Pencahayaan pada shoot ini terdiri atas pencahayaan terang dari matahari dan gelap ketika malam hari. Kondisi terkait dengan pencahayaan ini ingin menunjukkan bahwa di desa ini listrik masih menjadi hal yang langka. Fakta ini diperkuat dengan narasi yang ingin menyampaikan kepada penonton bahwa ada gap yang sangat jauh dari sisi kesejahteraan hidup antara masyarakat di desa 
kadai ini dengan masyarakat kota. Kondisi pada malam hari yang gelap gulita dengan ditemani suara jangkrik menunjukkan suasana yang sunyi di desa ini.

Pada level ideologi, menampilan sosok Yulius dan keluarganya yang hidup penuh semangat untuk kehidupan yang lebih baik Yulius bersemangat untuk sekolah, sedang ayahnya semangat berkebun demi memenuhi kebutuhan sehari-hari. Keadaan ini bisa dimasukkan kedalam kategori individual yang positif dan sarat akan nilai moral kepada para penonton. Disisi yang lain, keterbatasan bukan penghalang untuk tetap mempunyai pengharapan untuk hari esok.

Pada shoot Pak Muridn dan Sekolah TK \& Paud, level realitas dibangun melalui penampilan, riasan, makeup, cara berbicara, lingkungan, gerakan dan ekspresi. Komponen inilah yang membentuk pesan kepada penonton, sosok pak Muridin menunjukan seorang yang baik hati dan dermawan. Hal ini diperlihatkan dari tampilan gambar mengenai rumah dan listrik yang diberikan sebagai tempat sekolah TK dan Paud. Selain itu, pada bagian ini juga ditunjukkan keterlibatan kedua anaknya sebagai staf pengajar dan ada gerakan memegang meteran listrik dengan durasi 3 detik. Menurut penulis gerakan memegang meteran ini mempunyai pesan positif sekaligus negatif. Pesan positifnya adalah ia memberikan tanda bahwa meteran listrik inilah yang ia berikan kepada sekolah. Sedangkan pesan negatifnya, gerakan ini seperti gerakan memamerkan meteran listrik kepada para penonton. Pada bagian ini, penulis tidak melihat aktifitas di sekolah yang membutuhkan listrik, aktifitas disekolah yang terjadi adalah belajar mengajar dengan menggunakan papan tulis whiteboard dan terjadi pada saat matahari masih bersinar.

Level representatif dibangun melalui teknik gambar, setting atau latar tempat gambar diambil serta suara atau music. Teknik pengambilan gambar beragam diantaranya medium shoot, medium close up, group shoot, long shoot, dengan berbagai sudut pengambilan gambar seperti eye angle, high angel, dan over shoulder. Pengambilan gambar seperti ini memiliki tujuan untuk menunjukan dan membangun emosi penonton terhadap tayangan. Level ideologi tercermin melalui kategori individual yang dimiliki oleh pak muridin yaitu kebaikan hati dan dermawan. Hal ini diperlihatkan dari sebagian rumah yang ia berikan untuk digunakan sebagai sekolah.

Pada shoot Yosa sebagai warga lokal, diperlihatkan keseharian yosa sebagai anak angkat kepala Desa, selama menjalani tugasnya sebagai guru di SD Inpres Lekokadai. Yosa tinggal menetap di rumah kepala desa. Yosa membantu Ibu Wajumiati di kebun, memetik, dan memberi makan ternak. Pada level realitas, dibangun melalui kategori penampilan, riasan, makeup, lingkungan, cara berbicara, gerakan dan ekspresi yang menggambarkan Yosa seorang yang sederhana dan dekat dengan Ibu angkatnya. Hal ini diperlihatkan dari penampilan, riasan, makeup, ekspresi, serta gerakan-gerakan yang ada tayangan ini. Pada bagian ini memberi penggambaran jelas kepada penonton terkait dengan aktifitas Yosa ketika berada di rumah. Gambaran kehangatan hubungan Yosa dan ibu Wajumati 
diperlihatkan dari canda tawa yang tercipta selama memanen dan memberi makan ternak.

Pada level representatif, teknik kamera, seting atau latar tempat pengambilan objek, pencahayaan dan suara musik pengiring, membawa penonton masuk kedalam suasana yang dilakukan oleh objek. Teknik pengambilan gambar yang sama seperti shoot sebelumnya. Seting megambil tempat di kebun, dengan menggunakan pencahayaan alami dari matahari dan musik pengiring dengan instrument drum bertempo cepat. Iringan musik ini membawa suasana atau mood penonton kedalam aktiftas yang dilakukan oleh Yosa dan Ibu Wajumiati. Pada level ideologi, digambarkan dalam adegan Yosa sebagai seseorang yang rajin. Hal ini diperlihatkan dari aktifitas Yosa dalam membantu ibunya untuk memanen sayur di kebun dan memberi makan hewan ternak milik kepala desa.

Secara keselurahan, pesan yang disampaikan pada level ini adalah tampilan cerita hidup tokoh-tokoh selain tokoh utama yang sarat akan pemaknaan. Menurut penulis, pada segmen ini ingin menunjukkan nasib pendidikan di Indonesia yang memprihatinkan. Pendidikan di Indonesia belum tersebar secara merata baik di kota maupun di desa. Salah satu daerah yang kondisi pendidikannya masih memprihatinkan adalah pendidikan di Desa Lekokadai, Kepulauan Sula, Maluku Utara. Desa ini hanya memiliki satu Sekolah Dasar (SD) dan satu Taman Kana-kanan serta Paud yang menumpang di rumah salah seorang warganya. Kondisi ini seharusnya mendapat perhatian dari semua pihak yang memiliki tanggung jawab dalam bidang pendidikan, baik itu pemerintah pusat maupun pemerintah daerah. Pendidikan ini juga harus mendapat perhatian dari masyarakat Indonesia. Adanya kerjasama antara pemerintah dan masyarakat dalam bidang pendidikan, meningkatkan kualitas sumber daya manusia dan Indeks Pembangunan Manusia (IPM) masyarakat Indonesia semakin meningkat. Secara khusus desa lekokadai, yang saat ini menempati urutan ke-9 IPM di Maluku Utara.

Perhatian pemerintah untuk Desa Lekokadai, Kepulauan Sula, Maluku Utara ini seharusya bukan hanya pada bidang pendidikan saja. Fasilitas dan infrastruktur di desa Lekokadai yang masih jauh dari kata cukup ini seharusnya juga menjadi perhatian. Gap yang sangat tinggi dari fasilitas dan infrastruktur di desa ini dengan di kota-kota besar di Indonesia sudah saatnya diperkecil. Saatnya pemerintah pusat dan daerah lebih meningkatkan kesejahteraan masyarakat, sehingga fasilitas dan infrastruktur di desa ini semakin membaik. Fasilitas dan infrastruktur yang baik, akan mempengaruhi peningkatan perekonomian dan pendidikan di desa Lekokadai. 
Tabel 3. Penjelasan Segmen 3

\begin{tabular}{|c|c|c|}
\hline Level Realitas & Level Representatif & Level Ideologi \\
\hline $\begin{array}{l}\text { 1. Sederhana dan polos. } \\
\text { Penampilan, riasan dan } \\
\text { makeup yang digunakan } \\
\text { oleh para tokoh } \\
\text { sederhana dan polos. } \\
\text { 2. Gerakan. Gerakan yang } \\
\text { ada pada segmen ini } \\
\text { sesuai dengan aktivitas } \\
\text { yang dilakukan. } \\
\text { 3. Ekspresi. Ekspresi } \\
\text { beragam, ada canda tawa, } \\
\text { namun ada ekspresi tidak } \\
\text { nyaman dengan } \\
\text { diperlihatkan dari arah } \\
\text { mata yang mengecil } \\
\text { seolah menolak cahaya } \\
\text { matahari masuk. }\end{array}$ & $\begin{array}{l}\text { 1. Teknik pengambil } \\
\text { gambar. Teknik } \\
\text { pengambil gambar } \\
\text { beragam, dengan } \\
\text { sudut pengambilan } \\
\text { gambar beragam, hal } \\
\text { ini bertujuan untuk } \\
\text { menbangun mood } \\
\text { penonton agar bisa } \\
\text { memahami isi } \\
\text { tayangan dengan jelas. }\end{array}$ & 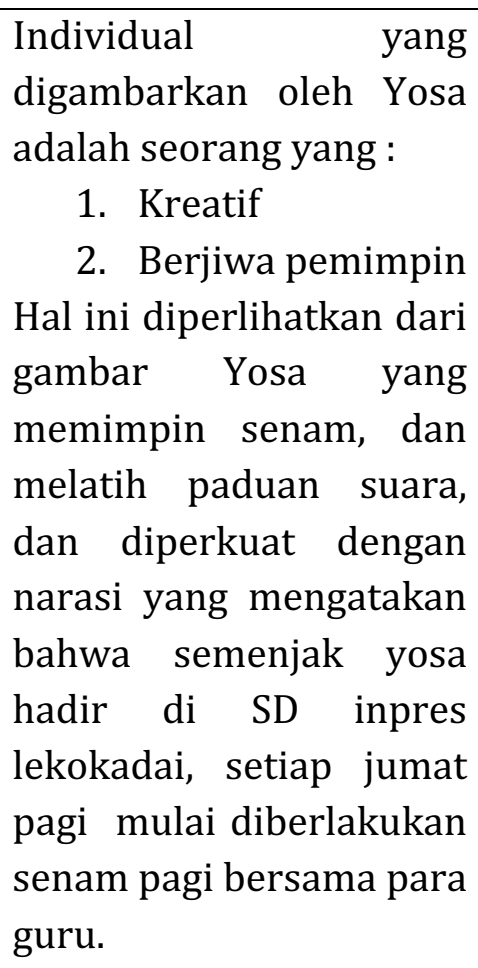 \\
\hline
\end{tabular}

Pada segmen ini, hanya terdiri dari 2 shoot yaitu tentang Yosa yang melakukan senam bersama guru-guru di SD Inpres Lekokadai dan Yosa yang memberi latihan paduan suara kepada anak-anak murid kelas 6 untuk tampil pada hari perpisahan dengan guru-guru dan teman-teman mereka. Berdasarkan pada tayangan pada segmen 3 ini, secara keseluruhan isi tayangannya terkait dengan kesenian yaitu senam dan paduan suara.

Mengacu dari semiotika John Fiske, analisis pada segmen ini terbagi kedalam 3 Level yaitu Level realitas, Level representatif dan Level ideologi. Level realitas dalam tayangan ini menunjukan banyak makna yang diperlihatkan dari kode-kode sosial yang termasuk dalam kategori, seperti: penampilan, riasan, makeup, perilaku, gerakan, ekspresi, cara berbicara dan lingkungan. Pada level representatif diperlihatkan dalam kategori, seperti tenik kamera, pencahayaan, setting atau latar tempat serta suara musik yang mengiringi. Level ideologi diperlihatkan melalui kategori individualitas. Tokoh utama digambarkan sebagai orang yang memberikan ide sehingga terlaksananya kedua kegiatan ini, yaitu senam dan latihan paduan suara.

Pada shoot senam, level realitas dibangun melalui penampilan, riasan, makeup, cara berbicara, ekspresi, gerakan dan lingkungan, penampilan pada shoot ini menggambarkan keseragaman yang disengaja. Pada bagian ini ditampilkan guru-guru dan Yosa yang menggunakan baju formal berwarna putih polos dan batik. Menurut penulis, pakaian ini tidak sesuai dengan aktiftas yang sedang dilakukan dalam tayangan yaitu senam. Pada 
umumnya senam dilakukan dengan berpakaian olahraga atau pakaian yang bisa menyerap keringat dengan baik.

Pada level representatif, melalui teknik gambar, seting tempat gambar diambil, pencahayaan dan musik pengiring memberi makna tersirat kepada penonton. Teknik gambar yang digunakan masih sama seperti pada tayangan sebelumnya, yaitu medium shoot dan long shoot gambar diambil dengan jarak dekat maupun jauh. Hal ini digunakan untuk membawa penonton kepada aktifitas yang dilakukan oleh objek. Menurut penulis, seting tempat tidak tepat. Hal ini diperlihatkan dari tempat yang digunakan oleh guruguru ketika melakukan senam di dalam ruangan guru dengan pencahayaan matahari yang kurang, karena pintu dan jendela yang tertutup. Hal ini tidak sama seperti senam yang dilakukan pada umumnya di tempat luas dengan pencahayaan matahari yang baik.Musik pengiringnya adalah lagu Pop daerah Maluku. Hal ini menunjukkan kemampuan masyarakat Maluku yang dijuluki oleh City of Musik di Indonesia, karena memiliki lagu dan digunakan untuk senam. Tidak hanya terkenal di daerah Maluku, lagu Pop Maluku ini sering digunakan untuk senam di berbagai daerah di Indonesia. Musik dengan tempo cepat ini sangat cocok untuk dijadikan sebagai lagu senam.

Pada level Ideologi, mengambarkan seorang Yosa yang penuh kreativitas. Hal ini di perlihatkan melalui ide Yosa untuk melakukan senam di sekolah untuk mengisi aktivitas di hari jumat pagi. Sayangnya, ide Yosa untuk melakukan senam di sekolah ini tidak melibatkan murid-murid untuk melakukan senam yang sama dengan guru-guru.

Pada shoot belajar paduan suara, level realitas dibangun melalui penampilan, riasan, makeup, cara berbicara, ekspresi, gerakan dan lingkungan. Yosa dan muridnya menunjukkan kesederhanaan dan kepolosan. Hal ini terlihat dari penampilan, riasan dan makeup yang digunakan. Ekspresi diperlihatkan dari salah satu murid Yosa, Jein Klause yang pandangan matanya tidak memandang lurus kedepan namun kebawah dengan gerakan mengecilkan kelopak mata seolah-olah menghalangi matahari untuk masuk ke mata pada saat menjadi solois untuk menyanyi lagu "You Raise Me Up" dari Josh Groban. Hal ini menunjukan ketidakpercayaan dan ketidaknyamanan.

Pada level representatif dibangun melalui teknik kamera, tempat gambar diambil, pencahayaan dan musik pengiring. Teknik kamera yang digunakan sangat beragam. Misalnya medium shoot, mediun close up, long shoot, dengan sudut pengambilan gambar yang beragam diantaranya: eye angle, over shoulder, dan high angel,. Teknik ini memiliki tujuan untuk memberi penjelasan kepada penonton agar penonton dapat masuk kedalam cerita yang dibangun pada tayangan. Tempat pengambilan gambar terjadi di lapangan sekolah Menurut penulis pemilihan tempat untuk berlatih paduan suara di tempat terbuka tidak tepat karena terlalu banyak ruang untuk mendengar jelas suara. Akibatnya, tidak dapat terdengar dengan jelas kesalahan-kesalahan yang dilakukan oleh para murid. Musik yang digunakan adalah music yang sama dengan prolog. Hal ini dilakukan untuk menunjukan kepada penonton bahwa tayangan akan segera berakhir. Penulis 
menganggap bahwa pemilihan lagu "You Raise Me Up" dari Josh Groban sebagai bentuk ucapan syukur kepada Tuhan Yang Maha Esa yang memberi kekuatan sehingga mereka anak murid kelas 6 telah selesai berjuang untuk menyelesaikan pendidikan di tingkat dasar dan akan terus dikuatkan untuk melewati badai setelah lulus dari SD untuk tahap selanjutnya oleh sang pencipta.

Secara keseluruhan, segmen ini menampilkan potensi daerah masyarakat Maluku yang kreatif dan berkarya di bidang musik, dan juga potensi anak-anak di Desa Lekokadai yang bisa bernyanyi dengan baik. Dalam pandangan penulis, tayangan pada segmen 3 ini ingin memperlihatkan kepada penonton bahwa inilah daerah yang di sebut dengan city of music in Indonesia. Daerah ini memiliki banyak potensi alami sejak dini, yang akan menjadi suatu kebanggan bagi desa dan daerahnya kelak.

Setiap kode-kode dalam ketiga tahapan ini membawa pemaknaan positif, membangun dan menginspirasi, didukung dengan data-data yang diperkuat melalui tayangan maupun narasi. Tayangan ini memberi inspirasi dari sisi yang berbeda, yaitu dari kehidupan sederhana masyarakat di Desa Lekokadai yang hidup dengan mengandalkan hasil kebun dan laut, serta keterbatasan akan arus listrik. Yang menarik, masyarakat di desa ini memiliki semangat untuk melakukan perubahan yang dimulai dari kesadaran akan pendidikan sejak dini. Pesan inilah yang menurut penulis ingin disampaikan kepada para penonton, yaitu pelajaran akan nilai moral untuk selalu mengabdi dengan ketulusan hati demi masa depan para penerus Bangsa Indonesia.

\section{SIMPULAN}

Perkembangan industri pertelevisian di Indonesia sangat cepat, hal ini seiring dengan berkembangnya teknologi informasi, pesan-pesan yang hendak disampaikan oleh media pun dilakukan melalui berbagai genre tayangan dari tayangan berita, hiburan, musik, talkshow, drama, olahraga, agama, kuis, film dan lain-lain yang target sasarannya berbeda-beda berdasarkan visi dan misi tayangan tersebut. Salah satu tayangan tersebut adalah tayangan documenter. Ciri-ciri dari tayangan documenter adalah tayangan yang menampilakan nilai realitas dengan fakta-fakta pendukung, serta tujuan akhirnya untuk mempengaruhi para penonton.

Dalam tayangan eps Yosa "Membina Potensi Para Penerus Bangsa di Kepulauan Sula, Maluku Utara" yang tayang pada 6 Mei 2018 ini sarat akan makna. Melalui pendekatan semiotika John Fiske, kode-kode sosial terbagi menjadi 3 tahapan yaitu level realitas, level representatif dan level ideologi dan semua level ini membawa sebuah pemaknaan baik secara tersirat maupun tersurat kepada para penonton. Penulis mendapatkan pemaknaan akan tokoh utama Yosa dengan cara sederhana, dilihat dari setiap cerita yang dibangun dari segmen 1 sampai 3. Tayangan ini mencerminkan kepribadian yang 
sederhana, kreatif, tegas, memiliki sifat pemimpin, dan mudah berbaur dengan lingkungan sekitar.

Selain Yosa sebagai tokoh utama, ada tokoh lain yang dihadirkan pada segmen kedua. Tayangan ini ingin menjelaskan kepada penonton bahwa tokoh-tokoh inspiratif bukan hanya Yosa, seorang pendatang di Desa Lekokadai. Pendudukan asli di desa ini juga memiliki cerita yang bisa menginspirasi para penonton.

Berdasarkan analisis pembahasan, maka pesan-pesan yang ingin disampaikan kepada Penonton melalui tayangan Lentera Indonesia episode Membina Potensi Para Penerus Bangsa di Kepulauan Sula, Maluku Utara" yang tayang pada 6 Mei 2018, adalah: (1) Pada segmen 1, Perjuangan seorang anak muda yang bernama Yosa dalam memperjuangkan pendidikan di daerah pelosok yang ada di Indonesia, dengan kepribadian yang sederhana, kreatif, tegas, memiliki sifat pemimpin, dan mudah berbaur dengan lingkungan sekitar. (2) Pada segmen 2, menunjukan pelajaran hidup yang menginspirasi, semangat perjuangan, kebaikan hati, kerelaan memberi, dan kehangatan yang datang dari tokoh-tokoh lain selain tokoh utama. (3) Pada segmen 3, penonton dibawa untuk menyaksikan potensi daerah Maluku yang dijuluki sebagai city of music in Indonesia.

Di sisi yang lain, tayangan Lentera Indonesia episode Membina Potensi Para Penerus Bangsa di Kepulauan Sula, Maluku Utara" yang tayang pada 6 Mei 2018 juga ingin mengkritisi tentang kondisi pendidikan di Indonesia yang belum merata, khususnya di Desa Lekokadai. Kesadaran tokoh Yosa yang mengambil bagian dalam pendidikan di daerah ini, ingin menyadarkan kepada pemerintah dan masyarakat tentang pentingnya sentuhan pemerintah (pusat dan daerah) serta masyarakat untuk terlibat dalam membangun pendidikan di daerah ini.

\section{DAFTAR PUSTAKA}

Deniss McQuail. 1987. Teori Komunikasi Masa: suatu pengantar. Jakarta: Erlangga.

Effendy, Onong Uchjana. 1993. Ilmu, Teori dan Filsafat Komunikasi, Bandung: Citra Aditya Bakti.

Fachrudin, Andi. 2016. Dasar-dasar Produksi Televisi: Produksi Berita, Ffeatur, Laporan Investigas, Dokumenter dan Teknik Editing, Jakarta: Prenada Media

Fiske, J. dan J. Hartley. 2003. Reading Television, $2^{\text {nd }}$ edition. London: Routhledge

Fiske, John. 2010. Cultural and communication studies: sebuha pengantar paling komprehensif. Yogyakarta: Jala Sutra 
Badan Statistik. 2017. Katalog Indek Pembangaunan Manusia Kabupaten Sula 2017. Badan Pusat Statistik Kepulauan Sula.

Navarro, Joe dan Marvin Karlins. 2017. Cara Cepat Membaca Bahasa Tubuh 2. Terjemahan dari what every body is saying $1^{\text {st }}$ Editon. Jakarta: PT. Zaytuna Ufuk Abadi.

Piliang, Yasraf A.2003. Hipersemiotika; Tafsir Cultural Studies Atas Matinya Makna. Yogyakarta: Jalasutra

Pratista, Himawan.2008. Memahami Film. Yogyakarta: Homerian Pusataka

Romli, Khomsahrial. 2016. Komunikasi Massa. Jakarta: Gramedia Widiasarana Idonesia Soyomukti, Nurani. 2010. Pengantar Ilmu Komnikasi. Yogyakarta: Ar- Ruzz Media Group

Wijayana, Widarmi. 2007. Mutiara Hitam Potensi Papua yang Tersembunyi. Yogyakarta: PT. Grasindo.

Wulandari, Eri Sri, dkk. 2016. Televisial, Merayakan Budaya Menonton, Membaca Program Televisi. Yogyakarta: Buku Litera 